\title{
データベース白書, 23年の軌跡
}

\section{The Database White Paper: Its locus for these 23 years}

\author{
根岸 正光 $^{1}$
}

\section{NEGISHI Masamitsu ${ }^{1}$}

1 国立情報学研究所（テ101-8430 東京都千代田区一ツ橋2-1-2）Tel:03-4212-2620 Fax:03-3556-1916 E-mail : negishi@nii.ac.jp 1 National Institute of Informatics (2-1-2 Hitotsubashi Chiyoda-ku, Tokyo 101-8430)

原稿受理 (2008-12-17)

(情報管理５1(11):799-805)

\section{1.はじめに}

「データベース白書」の発行元，(財)データベー ス振興センター (DPC: Database Promotion Center) は，わが国における各種のデータベース (DB) 活 動と, DB関連産業の振興を目的として1984年に設 立された。この当時，すでにデータベース・サー ビス業連絡懇談会 (DB懇) が1979年に設立され (1985年日本データベース協会DINAに改称) 活動し ていた。政府においても，通商産業省（当時）に より1983年に「データベース台帳総覧」が創刊さ れた。これはわが国で利用可能な「商用データベー ス」を一覧できるようにして，その利用を促進し ようとの意図に基づくものである。ここで「商用 データベース」とは, “Commercially Available Databases”の訳語であって, Dialog等のDBサービス を指す。DPCはこれら商用DBの構築・流通と, 企 業におけるイン八ウスDBの構築を振興して, わが 国の情報化を促進するための諸事業を展開した。 年刊の「データベース白書」の創刊はその重要な 一環であった。ここであらかじめデータベース白 書, 23年の軌跡を, 標題, 副題, ページ数等によ りまとめると表1のようである注1)。
2. データベース白書1986：創刊号

2.1 創刊号の年表から

データベース白書には，1986年の創刊号から， 巻末にDB関連事象の年表が付されている。創刊号 の年表は，環境，文献デー夕の電算化，検索シス テム・ネットワーク, DBサービスという区分で, アメリカの状況を整理している。DBサービスの振 興には,コンテンツ, アプリケーション，ネット ワークの3要素全体の進展が必要であるという, 極 めて適切な認識がすでにここに示されている。 年表には，米国におけるDB開発の契機とされる 1957年のスプートニク・ショックから始めて, DB 関連事業の振興を勧告した1963年のワインバーグ 報告も記載されている。「文献データの電算化」欄 には, CAS (Chemical Abstracts Service) のChemical Titles磁気テープ版の発行（61年）やIndex Medicus, Inspec, BIOSIS Previews等，60年代後半の展開があ る。「検索システム・ネットワーク」欄には, MIT TSS (60年)，NLM MEDLARSバッチシステム 63 年）があり，ネットワークでは72年TYMNET，74 年Telenet（後に現れたインターネット端末ソフト 
telnetではない) といったオンライン・アクセスの サービス開始がある。そして，DBサービスとして は，66年のNASA RECON，71年NLM MEDLINE，72年 ロッキードDialog等のサービス開始が掲げられて, DB先進国の米国では，オンラインDBが80年代にす でに普及期に入っていることがわかる。

わが国の状況については，環境，国内DBサービ ス, 海外DBサービスという3区分で整理を試みてい るが，これは外国製DBサービスの日本への進出が 盛んだった当時の状況を反映したものである。す なわち，72年紀伊國屋ASK，73年電通MARK-II，78 年丸善, 紀伊國屋Dialog代理業務開始といった事項 である。一方，国産DBサービスとしては70年の日 経NEEDS 財務・株価DB のMT販売, 72 年JICST と JAPATICのバッチサービスがあり, 以後, 72年日経 NEEDS-TS，76年JICST JOIS-I，78年PATOLIS，東京商 エリサーチTSR-COMPASS等のオンラインサービス が始まっている。ネットワークは, 80年KDD ICAS, 82年VENUS-Pにより, 海外DBへのオンライン・ア クセスも比較的安価に可能になった。

このようにDPC設立の1984年当時は，米国で商 用DBが普及しわが国へ進出してくる一方, 国内で も，経済情報，企業情報，特許情報，新聞記事，科
学技術文献情報の分野で独自にDBが構築され，才 ンラインでサービスされるようになり，これから 普及期を迎えようとする時期であった。

\section{2 データベース白書創刊}

データベース白書第1巻は, こうした中でわが国 におけるDBの発展を期して1986年5月に刊行され た。猪瀬博編集委員長 (当時) のまえがきによれ ば,「わが国のデータベース分野は残念ながらデー タベースの先進諸国，特に米国と比較すると，市 場の成熟度，政府施策，制度面はもとより，情報 に対する社会的意識においても非常に遅れてい る」という認識に基づき,「データベースについて のあらゆる側面を集大成してとりまとめ」て，そ の克服に資することを意図して発刊されたのであ る。その帯には,「広がる情報化の波, 脚光を浴び るデータベース」とある。

創刊号では，わが国DBの動向分析，先進諸国の 動向分析，各省庁の関連施策，DB技術のほか，人 材養成，パソコン通信, 社内（イン八ウス）・業界 DBにも章を立ててまとめている。さらに大部の資 料編が付されており，ここには，折から提示され

表1 データベース白書の軌跡

\begin{tabular}{|c|c|c|c|c|c|}
\hline 巻次 & 標題, 副題等 & 総頁数 & 巻次 & 標題, 副題等 & 総頁数 \\
\hline 1 & $\begin{array}{l}\text { データベース白書' } 86 \text { (帯) } \\
\text { 広がる情報化の波, 脚光を } \\
\text { 浴びるデータベース }\end{array}$ & 403 & 16 & $\begin{array}{l}\text { データベース白書2001：デジタル新 } \\
\text { 世紀における知的資源 }\end{array}$ & 472 \\
\hline 2 & データベース白書 1987 & 592 & 17 & 同2002 : ブロードバンド社会を支え & 419 \\
\hline 3 & 同1988 & 382 & 11 & る知的資源 & 419 \\
\hline 4 & 同1989 & 345 & 18 & 同2003 : ユビキタス社会を拓く知的 & 413 \\
\hline 5 & 同1990 & 394 & & 資源 & \\
\hline 6 & 同1991 & 343 & 19 & 同2004：ユビキタス社会を支える知 & 394 \\
\hline 7 & 同1992 & 369 & & 的資源 & 394 \\
\hline 8 & 同1993 & 350 & 20 & 同2005 (20周年記念号)：データベー & 376 \\
\hline 9 & 同1994 & 338 & $\angle 0$ & ス新時代へ向けて (以後A4版) & 310 \\
\hline 10 & 同1995 & 349 & 21 & 同2006:ナレッジ創出を支援する知 & 159 \\
\hline 11 & 同1996 & 369 & 21 & 的資源 & 109 \\
\hline 12 & 同1997 & 454 & 22 & 電子情報サービス2007:ネットに広 & 99 \\
\hline 13 & 同1998 & 450 & $\angle Z$ & がるコンテンツサービス & 99 \\
\hline 14 & 同1999 & 470 & 23 & 同2008: ウェブ社会のインフラと & 209 \\
\hline 15 & 同2000 & 461 & & なったデータベース & \\
\hline
\end{tabular}




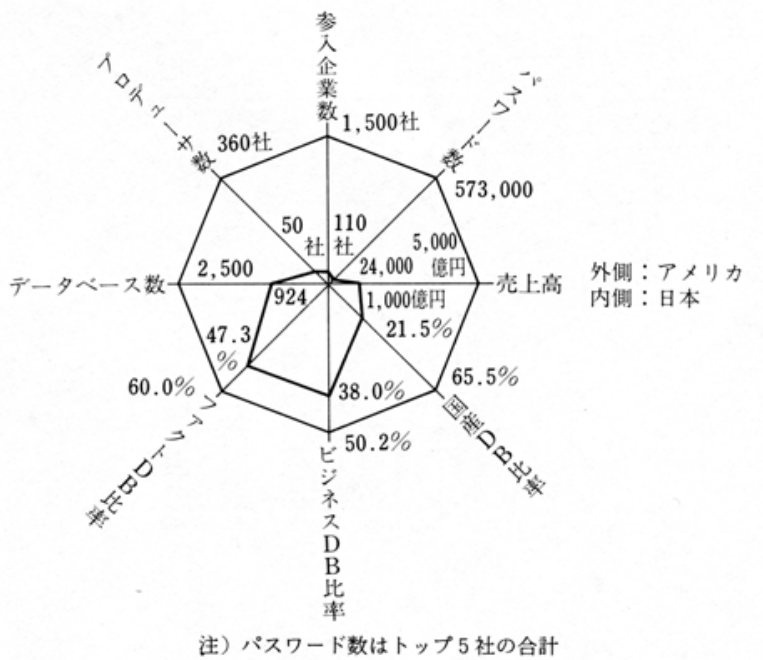

図1 日米データベース事情比較

（出典 : データベース白書1986, p.32）

た産業構造審議会情報産業部会の「データベース・ サービスに関する中間報告」, 情報産業振興議員連 盟データベース対策委員会の報告, また当時の中 曽根康弘総理大臣の諮問に応じた「高度情報社会 に関する懇談会」報告, DB懇のこれまでの提言等々 が収録され，当時のDB振興に対する意気込みが伝 わってくる。その内容の一端として, 総じて対米 10年遅れとの認識とともに揭げられた「日米デー タベース事情比較」と題するレーダー図をここに 再録しておく(図1)。

\section{3. データベース白書1996：Webと「オー プン型」データベース}

「データベース」というと，ともすればDBMS (Database Management System) を中心とするコン ピュータ技術の話題に集中しがちであるが，デー タベース白書の上記のような姿勢, すなわちDB自 体（その後の用語法でいうコンテンツ）の構築と その提供サービス，振興施策・制度等，ビジネス 的，社会的側面を見据えた編集方針はその後も貫 かれ，DBに関わる業界関係者すなわちプロデュー サー, ディストリビューターやエンド・ユーザー
を支援する図書館・資料室関係者に有益な最新情 報を提供してきた。

ところで，1995年ごろから一般にもにわかに普 及したインターネットは，DBサービスにも大きな 影響をもたらした。アクセス速度が飛躍的に向上 しただけでなく，とかく高額な通信料がかかった 国際アクセスが，内外の意識なく，しかも利用者 から見ると無料で使えるような環境が現出された のである。それ以前の商用データベースは時間制 課金のものが多く，したがって利用者は時間制に よるDB課金と通信料の双方のストレスの中であく せくと検索しなければならなかったが，この状況 が一変した。DB提供側でも，こうした環境に即し て，時間制課金からデー夕量課金へと料金体系を 改変して対処した。このことはDB利用者にとって は好ましいことであり，提供者側でも，通信され るデー夕量にさほど制約されずに，より高度な検 索機能を提供できるようになった。

こうした中でWebインターフェースによる簡易 検索機能を用いて，小規模ながら特定テーマにつ いて, 商用 (有料) でもイン八ウスでもなく, 無 料で公開される「データベース」が多数現れてき た。その多くは内容に片寄りがあったり，まとも に編集されていないような種類のものではある が，DB的であることは確かで，しかも無料一般公 開であることから相当数の利用者を獲得してい た。そこで白書1996ではDBの「定義」を見直し， これらのものを, 多少の無理は承知で「オープン 型」と称してさらに目配りすることにした。この 辺りから，インターネットとWebが従来型のDB サービスに大きな影響を与えるようになったこと がうかがえる。

さらに全世界のWebページを対象とする検索工 ンジンが現れると，インターネット自体が巨大な 「データベース」であり，しかもこれが瞬時に無料 で検索できるようになったことで，従来からのDB 
はもはや不要であるかのごとき皮相な主張も行わ れるようになり，1998年にGoogleの検索サービス が開始されると，この風潮は一層強まった。もっ とも後述のとおり,「プロ用のツール」としての商 用DBの価值はこれで損なわれるわけではなく, 着 実な進展が見られたのである。

\section{4. データベース白書2000：「情断」論再考}

データベース白書2000には, 新世紀を記念して, 冒頭に猪瀬先生の寄稿を掲げた。題して「デジタ ル新時代におけるデータベースのあり方：情断今 昔物語」というもので，オイルショックの「油断」 をもじって1983年に唱道された「情断」論，すな わち情報資源（DB，コンテンツ）の充実の必要性 を説いた提言を振り返り，2000年時点の状況を評 価されている。これによれば，政府施策では大き な進展が見られたものの, 民間保有デー夕の活用, DB化, 海外需要への対応等々なお未整備な事項が 指摘されている。さて, その後現在までの進展を どう見るか，これは読者諸賢に委ねたい。

2001年版以降はその年の状況に即した副題を付 すことにして，情報化社会の「知的資源」として のDBをアピールした（表1）。2002年版以降は，白 書の全文をPDF化し, Web版として, 冊子体白書の 購入者がアクセスできるようにし，現在，2006年 版以降が閲覧可能である。ここで創刊以来改訂さ れつつ収録されてきた「日米データベース事情比 較」図の2004年版を再録する (図2)。これの解説 は，わが国のDB産業は大いに発展を続けているも のの，米国の成長はそれにも増して急ピッチであ り，DB産業力の格差はむしろ広がっているのでは ないかといった論調になっている。

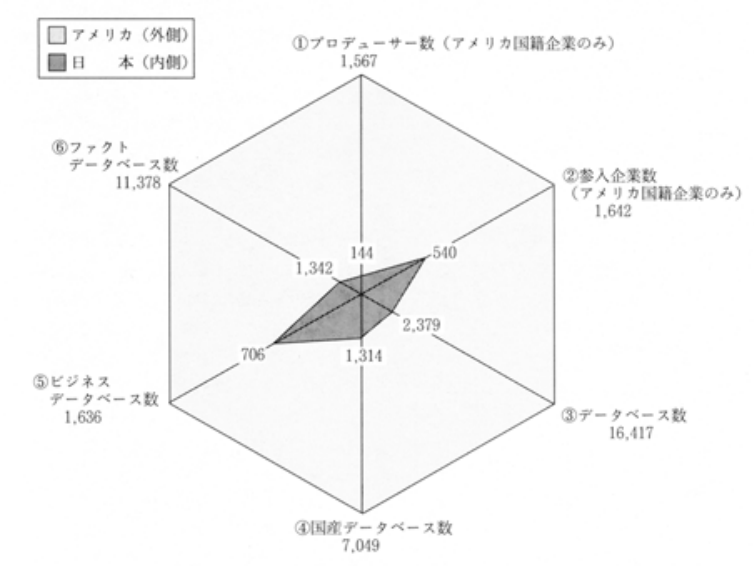

図2 日米データベース事情比較

(出典 : データベース白書2004, p.51)

\section{5. データベース白書2005：20周年記念号}

2005年版は白書創刊20周年記念号として, 冒頭 に35ページを費やした特集を掲げ，この20年間に おけるDBをとりまく技術，環境の変化とサービス 形態の変遷を整理している。また新聞記事DBを活 用して, 出現キーワード, 記事見出しを手がかり に，20年間の変動を跡づけた論稿もあって興味深 い。総じてこの特集は20年という長期変動を俯瞰 して，現状を理解するのにまことに有用なもので あり，折に触れて参照されることを読者諸氏に勧 めておきたい。

これによれば，国内で提供される商用DB数は 1985年には外国製1,008件：国産281件であったも のが，1997年には1,355：1,243と拮抗するに至り， 2003年には1,025:1,166となって，国産DBの充実 ぶりが見て取れる。DBサービスの売上高は1987年 に432億円であったが，2003年には3,118億円に達 し，これはこの間のGDPの伸びの5倍強の成長であ る。もっともこの成長は単調ではなく，90年代初 頭にかけての急成長の後, バブル崩壊の影響で足 踏み状況が続いたが, 1998年以降3,000億円近くの 水準を達成した。ただし2000年前後のネットバブ ル期に情報サービス業全体では急成長が実現した 
のに対して, DBサービスは横ばい傾向で推移して いる。これはDBが一応の普及安定状態に達したと みることができる。既述のオープン型DBの隆盛を 見れば，むしろ減少に転じても不思議でないので あるが，実際そうではないということは，商用DB がプロ用ツールとして安定的利用者層を獲得し, サービスとして定着していることを意味するとみ てよいであろう。

なおその後の動向として，DBサービス売上高は 2005年に3,600億円に達し，2006年では統計（特 定サービス産業実態調査）の改訂により直接比較 が困難になったものの，着実な成長が維持されて いると推測される（後出「電子情報サービス2008」 参照)。

\section{6. データベース・サービス実態調査}

データベース白書は，DB提供業者と利用者に対 するアンケート調査の結果を毎年収録し，その動 向を分析してきた。これはDPCで毎年実施される 「データベース・サービス実態調査」の結果に基づ くものである。この調査は1985年に「データベー ス・サービスに関するユーザー意識調査」として 開始されたもので, 当初は文字通りDBユーザー企 業に対する調査であったが，1987年度からはユー ザーと提供業者を区分した別々の調査票による，2 種類の調査を合わせたものになった。これを反映 して1993年度からは「データベース・サービス実 態調査」と改称され, 各々をユーザー編, ベンダー 編と称してとりまとめられるようになり，2005年 度（2006年3月公表）まで, 時代に合わせて調査 項目を改定しつつ同様の枠組みで実施された。

これにより，ユーザー編では，よく利用される DBサービスの具体例やユーザーとして今後望まれ るサービスのあり方等々が明らかになり, ベン ダー編では, 売上高の推移と予想や今後のサービ
ス展開等に関する回答が得られた。これは報告書 として公表されるほか, その要点が動向分析とと もに各年の白書に収録されて, DB関係者に広く提 供されてきた。

なお，この調査は後述のDPCの(財)日本情報処理 開発協会 (JIPDEC: Japan Information Processing Development Corporation) への統合後も「企業を対 象とした電子情報サービス利用の実態調査」とし て2006，2007年度に実施された。またこれに加え て「個人を対象とした電子情報サービス利用の実 態調査」も実施され，その結果も「電子情報サ一 ビス」に反映されている。ちなみに，2007年度の 企業ユーザーを対象とする調査における利用頻度 上位のサービスは, 帝国データバンク COSMOSNET, 日経テレコン21, 科学技術振興機構 JDream I, 東京商エリサーチtsr-van2など, 創刊号 の年表以来おなじみの顔ぶれが並んでいる。

\section{7. データベース白書英語版「イノセ・レ ポート」と日米情報摩擦}

ここで話題は前に戻るが，データベース白書は その創刊号から英語の要約版が作成された。すな わち “Database White Paper 1986”であり，翌年に は “Database Services in Japan 1987” と改称され, さらに “Databases in Japan 1988” となって, 以後 “Databases in Japan 2004”まで毎年発行された1)。 ここにはわが国のDBの海外からの利用法等, 外国 向きの事項も盛られている。

英語版発行の背景には80年代後半における「日 米情報摩擦」がある。折から日本経済はその後バ ブルと称される好況にあり，低迷する米国経済を 凌駕するという「ジャパンアズナンバーワン」の 時代であった。これに対して米国からは「日本は 日本語という非関税障壁をもって重要な情報への 外国からのアクセスを妨害しており，このため米 
国企業の日本への進出が阻害され，日本側の一方 的優勢になっている。外国にとって必要な情報は 英語化して発信するべきである」といつた，言い 掛かりともいえる主張がなされた。この問題を議 論するため,「第1回科学技術と商業に関する日本 情報国際会議」が1987年9月に英国Warwickで開催 され，その後，1997年7月ワシントンでの第5回ま で2年ごとに開催されたのである。実際，米国は 1986年に「日本技術文献法」を制定して，日本情 報の導入に力を入れ，わが国に対しても国産DBの 英語化や海外からのアクセスの改善を強く要求し てきた時代であった。

こうした情勢下, 当時のDPCの渡辺龍雄專務理事 が,「データベース白書の英語版は, 『イノセ・レ ポート』と称されて海外で高く評価されている」 と，誇らしげに語っておられたのが懐かしく思い 出される。ともあれ, 日米情報摩擦は, その後の 日米景況の再逆転により自然消滅し，今ではその 意味を想像することさえできないような状況にあ る。

\section{8.「電子情報サービス」：データベース白 書改題}

2006年4月にDPCがJPDECに統合されるに伴い, 「データベース白書」は「電子情報サービス」と改 題して再発足することになった。すでに触れたよ うに，インターネット，Webの普及により，DB概 念が拡張ないし拡散され，これは特にWeb2.0とい われる状況に至ってさらに加速している。そこで これを包摂するような用語として，「電子情報サー ビス」を設定し，事態をより幅広くとらえ，分析 しようという意図によるものであり, その新装2巻 目である「電子情報サービス2008」は2008年5月 に刊行された。

もっとも, Web2.0の元祖ティム・オライリーも, 「データは次代のintel insideである」としてDBの重要 性を指摘している。実際，基盤となるしつかりと したDBがなければ，まともな情報サービスは成立 しない。集合知による予定調和説などは，無から 有を生む錬金術に類するものではなかろうか。「電 子情報サービス2008」の副題,「ウェブ社会のイン フラとなったデータベース」はこの辺りの事情を よく表現していると思われる。

昨今では，検索エンジンを使えばあらゆる情報 が無料で入手できるかのごとき感覚が一般に浸透 しているが，これは皮相な理解である。まともな 情報の収集, 整序にはそれ相応の費用がかかる。要 はその費用負担の構造，すなわちビジネス・モデ ルが多様化して，例えば広告料収入でまかなうな よ゙，ユーザーに直接的な課金をしないものが多く なっているに過ぎない。この辺りの事情を解き明 かし，情報に対する正しい評価ができるようにす るための情報リテラシー教育は，以前にも増して 重要になってきていると思われる。この意味でも, データベース白書が採り上げてきたような解説や 分析は今後なお重要性を増すものと考える次第で ある。

\section{9. おわりに}

著者は，1993年に初代データベース白書編集委 員長であった猪瀬先生がDPC理事長に就任するに 際して, その後任を仰せつかり，1994年版以降， 編集委員長を何とか務めて現在に至った。今般著 者は2008年10月の第37回情報化月間において, 「『データベース白書』等で情報産業界の課題と動 向を情報産業のみならず一般社会にも明らかにす るなど，国民の認識向上に寄与した」として，情 報化促進部門の経済産業大臣表彰を受けた。

受賞理由に見るとおり，これは著者個人の功績 に帰するものではなく，23年の長きにわたるデー 
タベース白書の編集発刊事業が, わが国の情報化

に大きく貢献してきたと認められ，ここに顕彰さ

れたものである。この際，DPC，JPPECの関係各位
をはじめとして, 白書の執筆 · 編集 ·発行に携わ られた多くの方々の長年の努力に対して, 改めて 深甚なる敬意を表して本稿の結びとしたい。

\section{本文の注}

注1) データベース白書, データベース・サービス実態調査, Databases in Japan等を含むデータベース 振興センター(JPDEC/DPC)の刊行物の一覧は, 同センターHPの「刊行物」のページに掲示され ている。http://www.dpc.jipdec.or.jp/, (参照2008-12-14).

\section{参考文献}

1) Database Promotion Center, JAPAN. Databases in Japan 2004. 2004, 51 p. http://www.dpc.jipdec.or.jp/ english/Databases_in_Japan2004.pdf, (accessed 2008-12-14).

\section{著者抄録}

1986年に創刊された「データベース白書」は，2008年5月刊行の「電子情報サービス2008」をもって23年 目となつた。本稿では，この間の白書各年版の内容を振り返りつつ，わが国におけるデータベース関連諸 分野の変動を跡づけ，今後の展望に資するものとしたい。

キーワード

データベース,データベース白書, 情報化, インターネット, 情報サービス

\section{Author Abstract}

"The Database White Paper" was first published in 1986 and "Electronic Information Services 2008" has marked its 23rd year. The paper traces the changes in database related activities in Japan for these years by examining the annual editions of the White Paper, and would serve readers to foresee the future direction.

\section{Key words}

database, The Database White Paper, informatization, internet, information service 